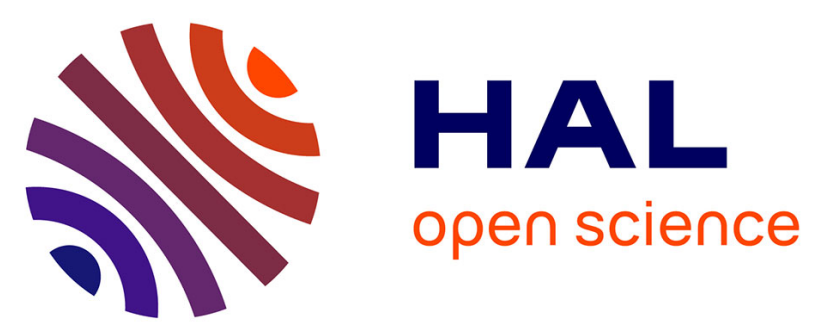

\title{
Non-essential and essential trace element concentrations in meat in cattle reared under organic, intensive or conventional production systems
}

Isabel Blanco-Penedo, Marta López Alonso, Marta Miranda, Joaquin

Hernández, José Luis Benedito, Richard Frederick Shore

\section{To cite this version:}

Isabel Blanco-Penedo, Marta López Alonso, Marta Miranda, Joaquin Hernández, José Luis Benedito, et al.. Non-essential and essential trace element concentrations in meat in cattle reared under organic, intensive or conventional production systems. Food Additives and Contaminants, 2009, 27 (01), pp.3642. 10.1080/02652030903161598. hal-00573901

\section{HAL Id: hal-00573901 \\ https://hal.science/hal-00573901}

Submitted on 5 Mar 2011

HAL is a multi-disciplinary open access archive for the deposit and dissemination of scientific research documents, whether they are published or not. The documents may come from teaching and research institutions in France or abroad, or from public or private research centers.
L'archive ouverte pluridisciplinaire HAL, est destinée au dépôt et à la diffusion de documents scientifiques de niveau recherche, publiés ou non, émanant des établissements d'enseignement et de recherche français ou étrangers, des laboratoires publics ou privés. 


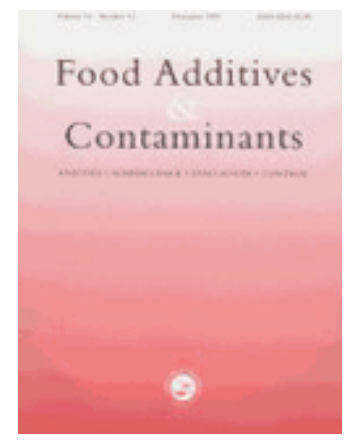

\section{Non-essential and essential trace element concentrations in meat in cattle reared under organic, intensive or conventional production systems}

\begin{tabular}{|c|c|}
\hline Journal: & Food Additives and Contaminants \\
\hline Manuscript ID: & TFAC-2009-043.R1 \\
\hline Manuscript Type: & Original Research Paper \\
\hline $\begin{array}{r}\text { Date Submitted by the } \\
\text { Author: }\end{array}$ & 30-Jun-2009 \\
\hline Complete List of Authors: & $\begin{array}{l}\text { Blanco-Penedo, Isabel; University of Santiago de Compostela, } \\
\text { Animal Pathology } \\
\text { Alonso, Marta; University of Santiago de Compostela, Animal } \\
\text { Pathology } \\
\text { Miranda, Marta; University of Santiago de Compostela, Ciencias } \\
\text { Clínicas Veterinarias } \\
\text { Hernández, Joaquin; University of Santiago de Compostela, Animal } \\
\text { Pathology } \\
\text { Benedito, José; University of Santiago de Compostela, Animal } \\
\text { Pathology } \\
\text { Shore, Richard; Lancaster Environment Centre, c Centre for Ecology } \\
\text { \& Hydrology }\end{array}$ \\
\hline Methods/Techniques: & Metals analysis - ICP, Toxicology - animal study \\
\hline Additives/Contaminants: & Toxic elements, Trace elements \\
\hline Food Types: & Animal products - meat \\
\hline
\end{tabular}

\section{SCHOLARONE ${ }^{\text {w }}$ Manuscripts}


1 Non-essential and essential trace element concentrations in meat in cattle

2 reared under organic, intensive or conventional production systems

3 I. Blanco-Penedo ${ }^{a}$, M. López-Alonso ${ }^{a^{*}}, M$ Miranda ${ }^{b}$, J. Hernández $^{a}$, J.L. Benedito ${ }^{a}$,

4 R.F. Shore

5 a Universidade de Santiago de Compostela, Departamento de Patoloxía Animal,

6 Facultade de Veterinaria, 27002 Lugo, Spain. ${ }^{b}$ Universidade de Santiago de

7 Compostela, Ciencias Clínicas Veterinarias, Facultade de Veterinaria, 27002 Lugo,

8 Spain. ${ }^{\circ}$ Centre for Ecology \& Hydrology, Lancaster Environment Centre, Library

9 Avenue, Bailrigg, Lancaster LA1 4AP, UK.

10

11

12

\section{Abstract}

We evaluated if differences in non-essential and essential trace element accumulation in beef-cattle reared under different systems (including organic, conventional and intensive management) were reflected in the meat derived from these animals. Diaphragm muscle from 166 calves from nine farms were analysed. Muscle cadmium concentrations were low ( $<10 \mu \mathrm{g} / \mathrm{kg}$ wet wt.) and muscle arsenic, mercury and lead concentrations were below limits of detection $(<12,2$ and $3 \mu \mathrm{g} / \mathrm{kg}$ respectively) in most (77-97\%) samples; there were no significant differences between farms. Essential trace element concentrations in muscle were generally within adequate physiological ranges and, although they varied significantly between farms, this was not apparently related to management practices. There were no significant correlations in element concentrations between muscle and liver or kidney (organ concentrations that better reflect exposure), except for cobalt 
23 (positive association) and zinc (negative association). Non-essential and essential 24 trace element concentrations in muscle in our study animals thus did not generally 25 reflect differences in exposure. This is particularly relevant for animals reared in 26 systems (such as organic farms) where cattle are exposed to somewhat higher 27 levels of non-essential elements (probably due to soil ingestion when grazing) but 28 also can suffer from mineral deficiencies.

29

30 Keywords: beef cattle; farming systems; non-essential elements; essential trace 31 elements; muscle; nutrition.

32

$33{ }^{*}$ Corresponding author: M López-Alonso. E-mail: marta.lopez.alonso@usc.es. 
35

36

37

38

39

40

41

42

43

44

45

46

47

48

49

50

51

52

53

54

55

56

57

\section{Introduction}

There have been various food scares over the past decade that has involved meat products. These include Salmonella in chicken, antibiotics in pork, Escherichia coli and banned growth promoters in beef, and the BSE crisis (Tarrant, 1998; Gambelli et al. 2003). These have contributed to a growing consumer awareness of food production methods that do not use chemicals and that are more in harmony with the natural environment. This, together with promotion of the importance of healthy food, has contributed to the recent rapid development of organic farming in the European Union (Vaarst and Hovi, 2004; von Borell and von Sorensen, 2004; Willer and Yussefi, 2006). Organic farming practices represent an alternative to the progressive intensification that has occurred in conventional animal production.

The quality of organic beef is affected by the production system used, particularly with respect to the grazing and exercise regimes which are integral components of any organic beef production system (Nielsen and Thamsborg, 2005). It is well documented that grazing cattle involuntarily ingest a certain amount of soil (up to 18\%; Thornton and Abrahams, 1983) which can lead to a significant exposure to non-essential elements and other toxic compounds (such as pesticides, microbiological toxins, and medicinal products) that may be present in the soil (Falandysz et al., 1994; Sharpe and Livesey, 2005). This exposure scenario has also been described for other livestock species, such as organically-reared pigs (Linden et al. 2001) and hens (Kijlstra 2004). However, home-grown feed, and accompanying restrictions on mineral supplementation, can also lead to dietary deficiencies in organically farmed animals (Falandysz, 1993; Vaarst and Hovi, 
58 2004). In particular, restrictions on feed supplements and prophylactic parasite

59 control in organic beef production can lead to mineral deficiencies (Roderick and

60 Hovi, 1999; MacNaeidhe, 2001) and result in poor body condition and production.

61 Thus, there are potential conflicts between practices that are employed to ensure

62 food safety and promote more "natural" livestock production and those used to

63 enhance animal welfare (Vaarst and Hovi, 2004).

64 In terms of meat quality, different feeding systems have been studied to assess

65 product quality in relation to post-mortem proteolysis, tenderness, meat flavour

66 (Andersen et al. 2005) and chemical residues-mainly hormones and antibiotics

67 (Smith et al. 1997). Although it has been well documented that farm practices can

68 significantly affect assimilation by cattle of non-essential elements in key organs

69 such as the liver and kidneys (López-Alonso et al. 2000), there is no information,

70 as far as we are aware, on how can such practices affect non-essential and

71 essential trace element concentrations in muscle, the main cattle product eaten by

72 people.

73 We have recently examined how the assimilation of non-essential and essential

74 trace element concentrations differs in the liver and kidneys of beef cattle in NW

75 Spain between farms that vary in their production systems, particularly in the extent

76 to which they graze cattle on pasture and provide dietary concentrates (Blanco-

77 Penedo et al. 2008, 2009). Calves that were from farms which largely or 78 exclusively grazed livestock on pasture and provided little or no mineral

79 supplementation had the highest tissue concentrations of non-essential elements.

80 We hypothesise that this is because pasture-grazed cattle ingest soil particles to 
81 which non-essential elements adhere. There was also evidence of some essential

82 trace element deficiency in cattle from farms that use low amounts of concentrates

83 and do not provide mineral supplements. The objective of the current study was to

84 evaluate if differences in non-essential and essential trace element accumulation

85 by cattle that are related to farm production practices are reflected in meat destined

86 for human consumption.

87

88

89

90

91

92

93

94

95

96

97 summarised elsewhere (Blanco-Penedo et al. 2008, 2009).

\section{Material and methods}

\section{Farm selection}

Farms were selected from the districts of Baralla (B), Montederramo (M) and Vilalba (V) in Galicia (NW Spain). In each district, a conventional (C), intensive (I) and organic $(\mathrm{O})$ farm from the same neighbourhood were selected. The farms were similar in most respects other than their grazing and supplementary feeding regimes. Detailed information including farm size, feeding regime, other husbandry and management practices, and non-essential and essential trace element concentrations in soils and diet (forage and concentrate feed) have been 
101 packed in plastic bags, immediately placed on ice, transported to the laboratory,

102 then stored at $-18^{\circ} \mathrm{C}$ until processing.

103 Sample analysis

104 Approximately $2 \mathrm{~g}$ sub-samples were digested in $5 \mathrm{ml}$ of concentrated nitric acid 105 (Suprapur grade, Merck) and $2 \mathrm{ml}$ of $30 \% \mathrm{w} / \mathrm{v}$ hydrogen peroxide in a microwave 106 digestion system (Milestone, Ethos Plus; Italy). Digested samples were transferred 107 to polypropylene sample tubes and diluted to $25 \mathrm{ml}$ with ultra-pure water.

108 Elements present at very low concentrations (arsenic (As), cadmium (Cd), 109 chromium $(\mathrm{Cr})$, cobalt $(\mathrm{Co})$, nickel $(\mathrm{Ni})$, mercury $(\mathrm{Hg})$ and lead $(\mathrm{Pb}))$ were 110 determined by inductively coupled plasma mass spectrometry (ICP-MS;

111 VGElemental PlasmaQuad SOption) whereas elements that occurred at higher 112 concentrations (copper $(\mathrm{Cu})$, iron $(\mathrm{Fe})$, manganese $(\mathrm{Mn})$, molybdenum $(\mathrm{Mo})$, 113 selenium (Se) and zinc $(\mathrm{Zn})$ ) were determined by inductively coupled plasma 114 atomic emission spectrometry (ICP-OES; Perkin Elmer Optima 4300 DV). An 115 analytical quality control programme was applied throughout the study. Blanks 116 were run alongside samples and concentrations in samples were blank corrected 117 as necessary. The limits of detection in the acid digest were calculated as three 118 times the standard deviation of the reagent blanks (Table 1) and were based on 119 the mean sample weight analysed.

\section{Analytical Quality assurance}

121 Analytical recoveries were determined from a Certified Reference Material (Pig 122 kidney CRM 186, BCR Reference Materials, Belgium) that was analysed alongside 
123 unknowns. There was generally good agreement between the measured and 124 certified or indicative values (Table 1). The CRM was not certified for Co and Mo 125 and analytical recoveries were determined for these elements using samples 126 spiked at a concentration that gave absorbance values some 2-10 times greater 127 than the normal levels in muscle. Mean recoveries were $89 \%$ and $96 \%$ 128 respectively. The precision of the analytical method, calculated as the relative 129 standard deviation (RSD) of Co and Mo concentrations in 10 digests of the same 130 sample, were between 5.8 and $9.3 \%$.

\section{Statistical analysis}

132 All statistical analyses were done using the program SPSS for Windows (v.15.0).

133 Non-detectable concentrations were assigned a value of half the detection limit 134 when calculating mean element concentrations in muscle. Data were tested using 135 a Kolmogorov-Smirnov test and were generally not normally distributed. They were 136 therefore log-transformed before analysis, and average concentrations are 137 therefore given as geometric means.

138 One-way Analysis of Variance followed by Tukey's honest significant difference 139 (HSD) post-hoc tests were used to test for differences in non-essential and 140 essential trace element concentrations between farms. The significance of 141 correlations between the levels of non-essential and essential trace elements in 142 muscle and liver and kidney in each farm were calculated using Spearman rank 143 correlation analysis. In all cases statistical significance was taken to be indicated 144 by $p<0.05$. 
145

146

147

148

149

150

151

152

153

154

155

156

157

158

159

160

161

162

163

164

165

166

167

\section{Results and Discussion}

Non-essential element concentrations in muscle from cattle from different farms are presented in Table 2. Overall, concentrations were low, and with the exception of $\mathrm{Cd}$, most samples (96.6 \% for As and $\mathrm{Hg}, 77.3 \%$ for $\mathrm{Pb}$ ) had levels which were not detectable. The remainder of samples had concentrations close to the detection limit. Cd concentrations were all below $10 \mu \mathrm{g} / \mathrm{kg}$ wet weight. In general, non-essential element residues in meat in this study were similar to those described in previous studies in cattle in NW Spain (López-Alonso et al. 2000; 2004) and were within the range of those described in other countries (for review see López-Alonso et al. 2000). None of the samples analysed in the current study exceeded the maximum admissible levels for $\mathrm{Cd}$ and $\mathrm{Pb}(0.050$ and $0.01 \mathrm{mg} / \mathrm{kg}$ fresh weight respectively) established by the European Commission (2001). The European Commission has not established statutory limits for As and $\mathrm{Hg}$ but $\mathrm{Hg}$ residues, when detected, were 1000-fold lower than those allowed in fish (European Commission 2001).

No significant differences were found between farms in muscle $\mathrm{Cd}$ concentrations (mean values ranged from 3.16 to $4.07 \mu \mathrm{g} / \mathrm{kg}$ wet weight) nor in the proportion of samples with detectable residues for the other non-essential elements (Table 2). There was no significant association between $\mathrm{Cd}$ concentrations in muscle and those in the liver or kidney (Table 3). This is broadly consistent with findings elsewhere that suggest that muscle concentrations of non-essential elements, except perhaps for As, are not closely related to the level of exposure, (Vreman et al. 1988). 
168 Essential trace element concentrations in muscle from cattle from different farms 169 are presented in Figure 1. In general, and with the exception of Se, essential trace 170 element concentrations in cattle muscle were within the ranges described by Puls 171 (1994) as adequate and were similar to those reported for cattle muscle in most 172 other countries (for review see Jorhem et al. 1989; López-Alonso et al. 2000). In 173 contrast, Se concentrations in cattle from all farms in the current study were above 174 the normal range $(0.070-0.150 \mathrm{mg} / \mathrm{kg}$ wet weight; Puls 1994) and were higher than 175 concentrations reported in cattle elsewhere (Jorhem et al. 1989). Indeed, most 176 animals in the present study had muscle Se concentrations within the high (0.250$1770.500 \mathrm{mg} / \mathrm{kg})$ or toxic $(0.500-1.500 \mathrm{mg} / \mathrm{kg})$ range. However, the ranges for 178 essential element concentrations proposed by Puls (1994) are not comprehensive 179 and do not take into account possible differences between different types of 180 muscle. Comparison of results from separate studies superficially suggest that 181 essential trace element concentrations in muscle vary 2-3 fold between cattle from 182 different countries (Jorhem et al. 1989; López-Alonso et al. 2000) even when 183 essential trace element concentrations in the liver and kidneys are comparable and 184 within the adequate physiological range. However, differences in muscle element 185 concentrations more likely reflected differences in the type of muscle analysed. For 186 example, cattle diaphragm has been found to contain nearly twice the $\mathrm{Cu}$ and $\mathrm{Se}$ 187 concentration of pectoral muscle (López-Alonso et al. 2000; López-Alonso 188 unpublished data), perhaps reflecting greater metabolic activity in the diaphragm.

189 There were statistically significant differences between farms for most essential 190 trace element concentrations in muscle (Figure 1). As with inter-farm differences in 
191 liver and kidney concentrations (Blanco-Penedo et al. 2009), there was no

192 evidence of any specific pattern of differences between regions or different types of 193 farm. Cattle from the organic farm in Montederramo (MO) had the lowest mean Co, $194 \mathrm{Cu}$, Ni and Se concentrations found in our study. This was the only farm where a 195 high proportion of animals had hepatic Co and Se concentrations that were within 196 the marginal or deficient range, and (together with the organic farm in Baralla $197(\mathrm{BO}))$, had calves with hepatic $\mathrm{Cu}$ concentrations that were below the range 198 considered adequate (Blanco-Penedo et al. 2009). Calves from the MO farm also 199 had significantly higher $\mathrm{Zn}$ muscle concentrations than cattle from other farms 200 although, surprisingly, calves from the MO farm had the lowest mean $\mathrm{Zn}$ hepatic 201 and renal concentrations that we recorded (Blanco-Penedo et al. 2009). The 202 highest mean concentrations in muscle of most of the essential trace elements 203 (Cu, Fe, Mn, Mo and Se) were in cattle from the intensive farm in Vilalba (VI), 204 although it did not correspond with a higher intake of these elements in the diet or 205 higher concentrations in the liver or kidney (Blanco-Penedo et al. 2009).

206 When analysing the relationship between essential trace element concentrations in 207 muscle and those in the liver or kidney (data from Blanco-Penedo et al. 2009), the 208 only significant positive association was for Co; muscle Co concentrations were 209 positively associated with Co concentrations in both liver and kidney (Figure 2; 210 Table 3). There was also a significant negative association between $\mathrm{Zn}$ 211 concentrations in the muscle and those in the liver and kidney (Table 3). Taking 212 into account that essential trace element concentrations in the liver, and to a lesser 213 extent in the kidney, are the best indicators of the mineral status in calves (López- 
214 Alonso et al. 2000), our results indicate that, at least under the conditions of our 215 study, essential trace element concentration in muscle is generally not indicative of 216 mineral status. This is presumably because muscle, unlike the liver and kidney, 217 does not have essential trace element storage capacity. At adequate dietary 218 intakes, mineral concentrations in muscle may be most closely related to protein 219 synthesis and the predominant type of metabolism in the muscle (Schricker et al. 220 1982).

221 Although our results did suggest that muscle Co might correlate with Co status, this 222 has not been found elsewhere. Van Ryssen et al. (1987) compared tissue Co 223 concentrations in cattle given little or no dietary Co supplementation (Co 224 requirement in cattle is $0.1 \mathrm{mg} / \mathrm{kg} \mathrm{DM}$; NRC 2001) with those in cattle given large 225 Co supplements (10 and $40 \mathrm{mg} / \mathrm{kg} \mathrm{DM}$ ). The authors found that although liver and 226 pancreatic Co concentrations significantly increased with Co supplementation 227 (increase from 7.60 to $11.15 \mathrm{mg} / \mathrm{kg}$ dry weight in liver, and from 7.88 to 10.69 $228 \mathrm{mg} / \mathrm{kg}$ dry weight in the pancreas), there was no concomitant increase in muscle 229 Co (8.36 vs $8.56 \mathrm{mg} / \mathrm{kg}$ dry weight). It is possible that the low dietary levels of Co in 230 cattle in our study were below those necessary to maximise metabolic activity 231 (although normal or adequate Co concentrations have not been established for 232 muscle; Puls 1994) and so Co concentrations in the muscle of cattle from farms 233 where Co nutrition was better may have significantly increased alongside 234 concentrations in the liver and kidney.

235 The negative association that we found between $\mathrm{Zn}$ concentrations in the muscle 236 and those in the liver and kidney (Figure 3) was also surprising. In a previous study 
237 in cattle with adequate Zn status in NW Spain (López Alonso 1999), Zn

238 concentrations in the liver and kidney were strongly and positively correlated (as in

239 this study; $R_{s}=0.801, p<0.01$ ) but there was no significant association between

240 muscle $\mathrm{Zn}$ and either liver or kidney $\mathrm{Zn}$. In cattle, $\mathrm{Zn}$ tissue concentrations are

241 efficiently regulated by homeostatic mechanisms and, once optimal physiological

242 concentrations (30 mg/kg DM; NRC 2001) are reached, Zn supplementation has

243 no significant effect on Zn muscle levels (Kessler et al. 2003). Differences in tissue

$244 \mathrm{Zn}$ concentrations between cattle receiving adequate $\mathrm{Zn}$ dietary concentrations

245 could be due to factors such as age, sex, or production class (milk or beef cattle)

246 (Puschner et al. 2004). It is also possible that other dietary components may

247 influence the distribution of zinc in the body. For example other elements such as

$248 \mathrm{Cu}$ and $\mathrm{Cd}$ have similar chemical and physical properties to $\mathrm{Zn}$ and compete for

249 metabolic binding sites in metallothioneins (López-Alonso et al. 2002). It is possible

250 that the negative association between $\mathrm{Zn}$ concentrations in the muscle and liver

251 and kidney in the current study may be due, at least in part, to some of these

252 confounding factors.

253

254 Conclusions

255 Our results indicate that differences in non-essential and essential trace element 256 concentrations in the liver and kidney of cattle from different production systems on

257 farms in Galicia are not reflected in the non-essential and essential trace element

258 content in the meat. This is especially relevant for animals reared in systems (such 
259 as organic farms) where weaned calves are exclusively reared by being grazed on 260 pasture and, as a result, accumulate elevated hepatic and renal non-essential 261 element levels (probably due to soil ingestion) but also can suffer from mineral 262 deficiencies.

263

264 Acknowledgements

265 This study was supported by the Xunta de Galicia (Spain) 266 (PGIDT02RA6261001PR). I. B. P. is a recipient of a research fellowship (AP2003267 3835) from the Ministry of Science of Spain. We thank Nieves Muñoz for statistical 268 assistance.

269

270

\section{References}

271 Andersen HJ, Oksbjerg N, Young JF, Therkildsen M. 2005. Feeding and meat 272 quality- a future approach. Meat Sci. 70:543-554.

273 Blanco-Penedo I, Benedito JL, Shore RF, Miranda M, Castillo C, López-Alonso M. 274 2008. Farming factors affecting the accumulation of toxic chemical elements in 275 calves in NW Spain. Submitted. .

276 Blanco-Penedo I, Shore RF, Miranda M, Benedito JL, López-Alonso M. 2009. 277 Factors affecting trace element status in calves in NW Spain. Livest Sci. 123(2278 3):198-208. 
279 European Commission 2001. Commission Regulation EEC466/2001. Setting 280 Maximum Levels for certain contaminants in Foodstuffs. Commission of the 281 European Communities, Brussels.

282 Falandysz J. 1993. Some toxic and essential trace metals in swine from Northern 283 Poland. Sci Total Environ. 136:193-204.

284 Falandysz J, Kotecka W, Kannan K. 1994. Mercury, lead, cadmium, manganese, 285 copper, iron and zinc concentrations in poultry and sheep from the northern part of 286 Poland. Sci Total Environ. 141:51-57.

287 Gambelli D, Naspetti S, Vairo D. 2003. Why are consumers buying organic meat 288 and milk? A qualitative study of the Italian market. Proceeding of the 1st SAFO 289 Workshop; 5-7 September; Florence, Italy.

290 Jorhem L, Sundström B, Astrand C, Haegglund G. 1989. The levels of zinc, 291 manganese, selenium, chromium, nickel, cobalt, and aluminium in the meat, liver 292 and kidney of Swedish pigs and cattle. Z Lebensmi Unters Forsch. 188:39-44.

293 Kessler J, Morel I, Dufey P-A, Gutzwiller A, Stern A, Geyer H. 2003. Effect of 294 organic zinc resources on performance, zinc status and carcass, meat and claw 295 quality in fattening bulls. Livest Sci. 81:161-171.

296 Kijlstra A. 2004. The role of organic and free poultry production systems on the 297 dioxin levels in eggs. Proceedings of the 3rd SAFO Workshop, 16-18 September 298 2004, Falenty. Reading. 
299 Linden A, Andersson K, Oskarsson A. 2001. Cadmium in organic and conventional 300 pig production. Arch Environ Contam Toxicol. 40:425-431.

301 López Alonso M. 1999. Estudio de los principales elementos contaminantes en 302 Ganado vacuno de Galicia. PhD thesis, [Spain]: University of Santiago de 303 Compostela.

304 López-Alonso M, Benedito JL, Miranda M, Castillo C, Hernández J, Shore RF. 305 2000. Toxic and trace elements in liver, kidney and meat from cattle slaughtered in 306 Galicia (NW Spain). Food Addit Contam. 17:447-457.

307 López-Alonso M, Benedito JL, Miranda M, Castillo C, Hernández J, Shore RF. 308 2002. Contribution of cattle products to dietary intake of trace and toxic elements in 309 Galicia, Spain. Food Addit Contam. 19:533-541.

310 López-Alonso M, Prieto Montaña F, Miranda M, Castillo C, Hernández J, Benedito 311 JL. 2004. Interactions between toxic (As, $\mathrm{Cd}, \mathrm{Hg}$ and $\mathrm{Pb}$ ) and nutritional essential 312 (Ca, Co, Cr, Cu, Fe, Mn, Mo, Ni, Se, Zn) elements in the tissues of cattle from NW 313 Spain. BioMetals 17:389-397.

314 MacNaeidhe FS. 2001. Pasture management and composition as a means of 315 minimizing mineral disorders in organic livestock. Proceedings of the $5^{\text {th }}$ NAHWOA 316 Workshop; November; Rodding, Denmark.

317 NRC (National Research Council) (2001). Nutrient requirements of Beef Cattle. $7^{\text {th }}$ 318 revised edn. National Academic Press, Washington DC. 
319 Nielsen BK, Thamsborg SM. 2005. Welfare, health and product quality in organic

320 beef production: A Danish perspective. Livest Sci. 94:41-50.

321 Puls R. 1994. Mineral levels in animal health. Clearbrook: Sherpa International.

322 Puschner B, Choi Y-K, Tegzes JH, Thurmond MC. 2004. Influence of age, sex, and 323 production class on liver zinc concentration in calves. J Vet Diagn Invest. 16:278324282.

325 Roderick S, Hovi M. 1999. Animal health and welfare in organic livestock systems: 326 identification of constraints and priorities. A report to MAFF p. 65.

327 Schricker BR, Miller DD, Stouffer JR. 1982. Content of zinc in selected muscles 328 from beef, pork, and lamb. J Food Sci. 47:1020-1020.

329 Sharpe RT, Livesey CT. 2005. Surveillance of suspect animal toxicoses with 330 potential food safety implications in England and Wales between 1990 and 2002. 331 Vet Rec. 157:465-469.

332 Smith GC, Heaton KL, Sofos JN, Tatum JD, Aaronson MJ, Clayton RP. 1997. 333 Residues of antibiotics, hormones and pesticides in conventional, natural and 334 organic beef. J Muscle Foods. 8:157-172.

335 Tarrant PV. 1998. Some recent advances and future priorities in research for the 336 meat industry. Meat Sci. 49:S1-S16.

337 Thornton I, Abrahams P. 1983. Soil ingestion-a major pathway of heavy metals 338 into livestock grazing contaminated land. Sci Total Environ. 28:287-294. 
339 Vaarst M, Hovi M. (2004). Organic livestock production and food quality: a review 340 of current status and future challenges. Proceedings of the 2nd SAFO Workshop;

341 March 2004; Witzenhausen, Germany.

342 Van Ryssen JBJ, Miller WJ, Gentry RP, Neathery MW. 1987. Effect of added 343 dietary cobalt on metabolism and distribution of radioactive selenium and stable 344 minerals. J Dairy Sci. 70:639-644.

345 von Borell E, von Sorensen JT. 2004. Organic livestock production in Europe: 346 aims, rules and trends with special emphasis on animal health and welfare. Livest 347 Sci. 90:3-9.

348 Vreman K, van der Veen NG, van der Molen EJ, de Ruig WG. 1988. Transfer of 349 cadmium, lead, mercury and arsenic from feed into tissues of fattening bulls: 350 chemical and pathological data. Neth J Agr Sci. 36:327-338.

351 Willer M, Yussefi M. 2006. The World of Organic Agriculture: Statistics and 352 Emerging Trends. IFOAM, Bonn. 
353 Table 1. Results of the analytical quality control programme used in the 354 determination of non-essential and essential trace elements

\begin{tabular}{|c|c|c|c|c|}
\hline \multirow[t]{2}{*}{ Element } & \multirow{2}{*}{$\begin{array}{c}\text { Blank }(n=16) \\
\text { Mean } \pm S D \\
(\mu \mathrm{g} / \mathrm{l})\end{array}$} & \multirow{2}{*}{$\begin{array}{c}\text { Detection } \\
\quad \text { limit } \\
(\mu \mathrm{g} / \mathrm{g})\end{array}$} & \multicolumn{2}{|c|}{ Certified Reference Material } \\
\hline & & & $\begin{array}{c}\text { certified levels } \\
\text { mean } \pm \mathrm{SD}(\mathrm{mg} / \mathrm{kg})\end{array}$ & $\begin{array}{c}\text { analysed levels } \\
\text { mean } \pm \mathrm{SD}(\mathrm{mg} / \mathrm{kg})\end{array}$ \\
\hline As & $0.98 \pm 0.3$ & 0.012 & $0.063 \pm 0.009$ & $0.069 \pm 0.006$ \\
\hline Co & $0.04 \pm 0.2$ & 0.076 & --- & $0.151 \pm 0.054$ \\
\hline $\mathrm{Cr}$ & $0.5 \pm 0.26$ & 0.010 & $(0.058-0.142)$ & $0.198 \pm 0.043$ \\
\hline $\mathrm{Cd}$ & $0.10 \pm 0.03$ & 0.001 & $2.710 \pm 0.150$ & $2.711 \pm 0.122$ \\
\hline $\mathrm{Cu}$ & $3 \pm 1.9$ & 0.072 & $31.9 \pm 0.4$ & $29.1 \pm 1.48$ \\
\hline $\mathrm{Fe}$ & $29.5 \pm 1.66$ & 0.063 & $299 \pm 10$ & $283 \pm 15.8$ \\
\hline $\mathrm{Hg}$ & $0.15 \pm 0.05$ & 0.002 & $1.970 \pm 0.040$ & $1.852 \pm 0.111$ \\
\hline $\mathrm{Mn}$ & $0.69 \pm 1.00$ & 0.038 & $8.5 \pm 0.3$ & $7.85 \pm 0.51$ \\
\hline Mo & $0.58 \pm 0.36$ & 0.014 & --- & $3.39 \pm 0.29$ \\
\hline $\mathrm{Ni}$ & $0.95 \pm 0.05$ & 0.035 & $(0.420)$ & $0.544 \pm 0.256$ \\
\hline $\mathrm{Pb}$ & $0.235 \pm 0.09$ & 0.003 & $0.306 \pm 0.011$ & $0.318 \pm 0.041$ \\
\hline $\mathrm{Se}$ & $16.6 \pm 8.33$ & 0.317 & $10.3 \pm 0.5$ & $11.9 \pm 1.07$ \\
\hline $\mathrm{Zn}$ & $22.2 \pm 2.50$ & 0.095 & $128 \pm 3$ & $128 \pm 6.73$ \\
\hline
\end{tabular}


357 Table 2. Non-essential ( $\mathrm{As}, \mathrm{Cd}, \mathrm{Hg}$ and $\mathrm{Pb}$ ) element concentrations in muscle $358(\mu \mathrm{g} / \mathrm{kg}$ wet weight) in cattle in our study. Abbreviations for farms are as follows B:

359 Baralla, M: Montederramo, V: Vilalba, C: Conventional, I: Intensive, O: Organic

\begin{tabular}{|c|c|c|c|c|c|}
\hline \multicolumn{2}{|c|}{ Farm } & As & $\mathrm{Cd}$ & $\mathrm{Hg}$ & $\mathrm{Pb}$ \\
\hline \multirow[t]{3}{*}{$\mathrm{BC}$} & $\mathrm{N}(<\mathrm{d})$ & $13(13)$ & 13 & $13(13)$ & $13(11)$ \\
\hline & Geometric mean & ND & 3.73 & ND & 1.81 \\
\hline & Range & ND-ND & $2.10-6.13$ & ND-ND & ND-15.6 \\
\hline \multirow[t]{3}{*}{$\mathrm{BI}$} & $N(<l d)$ & $14(13)$ & 14 & $14(14)$ & $14(12)$ \\
\hline & Geometric mean & 6.83 & 3.48 & ND & 1.75 \\
\hline & Range & ND-28.1 & $1.82-5.62$ & ND-ND & ND-11.7 \\
\hline \multirow[t]{3}{*}{ BO } & $N(<\mathrm{d})$ & $14(14)$ & 14 & $14(13)$ & $14(11)$ \\
\hline & Geometric mean & ND & 3.62 & 1.06 & 2.15 \\
\hline & Range & ND-ND & $2.28-6.60$ & ND-5.56 & ND-18.9 \\
\hline \multirow[t]{3}{*}{ MC } & $N(<\mathrm{d})$ & $14(14)$ & 14 & $14(13)$ & $14(11)$ \\
\hline & Geometric mean & ND & 3.16 & 1.03 & 2.13 \\
\hline & Range & ND-ND & $1.87-4.86$ & ND-3.30 & ND-18.0 \\
\hline \multirow[t]{3}{*}{ MI } & $\mathrm{N}(<\mathrm{d})$ & $13(11)$ & 13 & 13 (13) & $13(9)$ \\
\hline & Geometric mean & 6.95 & 3.57 & ND & 2.42 \\
\hline & Range & ND-14.5 & 2.16-7.05 & ND-ND & ND-5.83 \\
\hline \multirow[t]{3}{*}{ MO } & $N(<\mathrm{ld})$ & $8(7)$ & 8 & $8(8)$ & $8(7)$ \\
\hline & Geometric mean & 6.82 & 3.20 & ND & 1.93 \\
\hline & Range & ND-14.5 & $2.02-5.81$ & ND-ND & ND-10.5 \\
\hline \multirow[t]{3}{*}{ VC } & $N(<\mathrm{ld})$ & $14(14)$ & 14 & $14(14)$ & $14(11)$ \\
\hline & Geometric mean & ND & 4.07 & ND & 2.16 \\
\hline & Range & ND-ND & $2.76-7.21$ & ND-ND & ND-8.91 \\
\hline \multirow[t]{3}{*}{$\mathrm{VI}$} & $N(<\mathrm{ld})$ & $14(14)$ & 13 & 14 (13) & $14(10)$ \\
\hline & Geomet & ND & 3.59 & 1.07 & 2.25 \\
\hline & Range & ND-ND & $1.72-5.67$ & ND-5.78 & ND-15.7 \\
\hline \multirow[t]{3}{*}{ VO } & $\mathrm{N}(<\mathrm{ld})$ & $15(15)$ & 15 & $15(14)$ & $15(11)$ \\
\hline & Geometric mean & ND & 4.02 & 1.05 & 2.17 \\
\hline & Range & ND-ND & $1.76-8.93$ & ND-5.22 & ND-7.20 \\
\hline
\end{tabular}


362 Table 3. Rank correlations between mean non-essential and essential trace 363 element concentrations in muscle and liver and kidney in each farm in cattle in our 364 study. Results are expressed as Spearman rank correlations coefficient and 365 probability $\left({ }^{\star} p<0.05,{ }^{*} p<0.01,{ }^{* \star *} p<0.001\right)$. Correlations have been not calculated 366 for $\mathrm{As}, \mathrm{Hg}$ and $\mathrm{Pb}$ because most samples had not detectable concentrations

\begin{tabular}{lll}
\hline Element $(\mathrm{N})$ & Muscle vs. liver & Muscle vs. kidney \\
\hline Cd $(118)$ & -0.247 & -0.165 \\
Co $(119)$ & $0.875^{* *}$ & $0.913^{* * *}$ \\
Cr (119) & -0.089 & -0.367 \\
Cu (164) & 0.120 & 0.594 \\
Fe (166) & -0.074 & -0.137 \\
Ni $(119)$ & 0.224 & 0.535 \\
Mn (165) & 0.608 & 0.325 \\
Mo (165) & 0.133 & -0.587 \\
Se $(166)$ & 0.256 & -0.104 \\
Zn $(166)$ & $-0.837^{* *}$ & $-0.704^{*}$ \\
\hline
\end{tabular}


368 Figure captions

369 Figure 1. Bar chart showing essential trace element concentrations in muscle 370 (expressed as geometric means and geometric standard error) in the farms in our 371 study. Abbreviations for farms are as follows B: Baralla, M: Montederramo, V: 372 Vilalba, C: Conventional, I: Intensive, O: Organic. Different letters denote 373 statistically significant differences between farms at $p<0.05$.

374 Figure 2. Scatterplot showing the relationship between Co concentrations in the 375 muscle and liver and kidney.

376 Figure 3. Scatterplot showing the relationship between $\mathrm{Zn}$ concentrations in the 377 muscle and liver and kidney. 

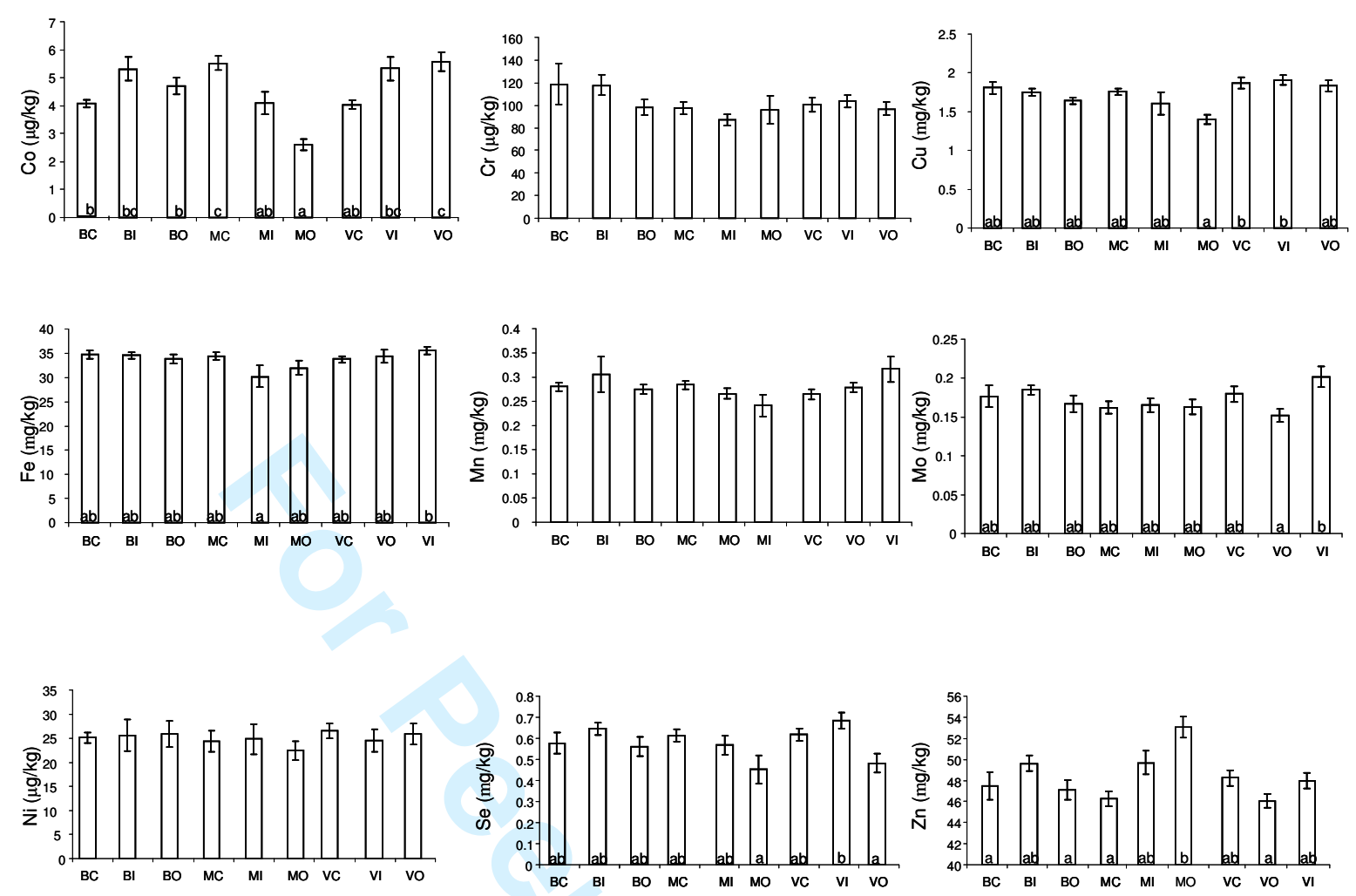

Figure 1. 

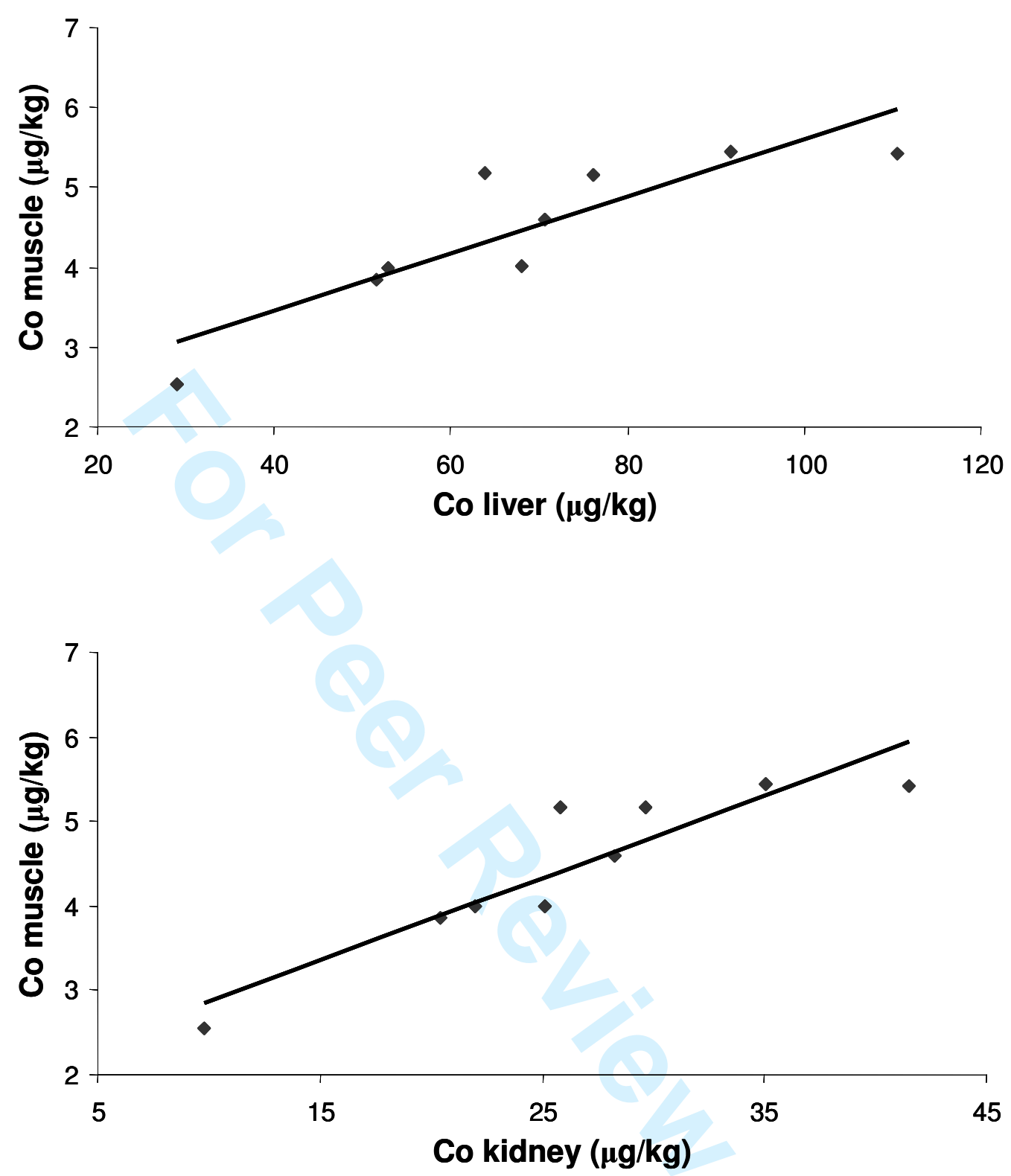

Figure 2. 

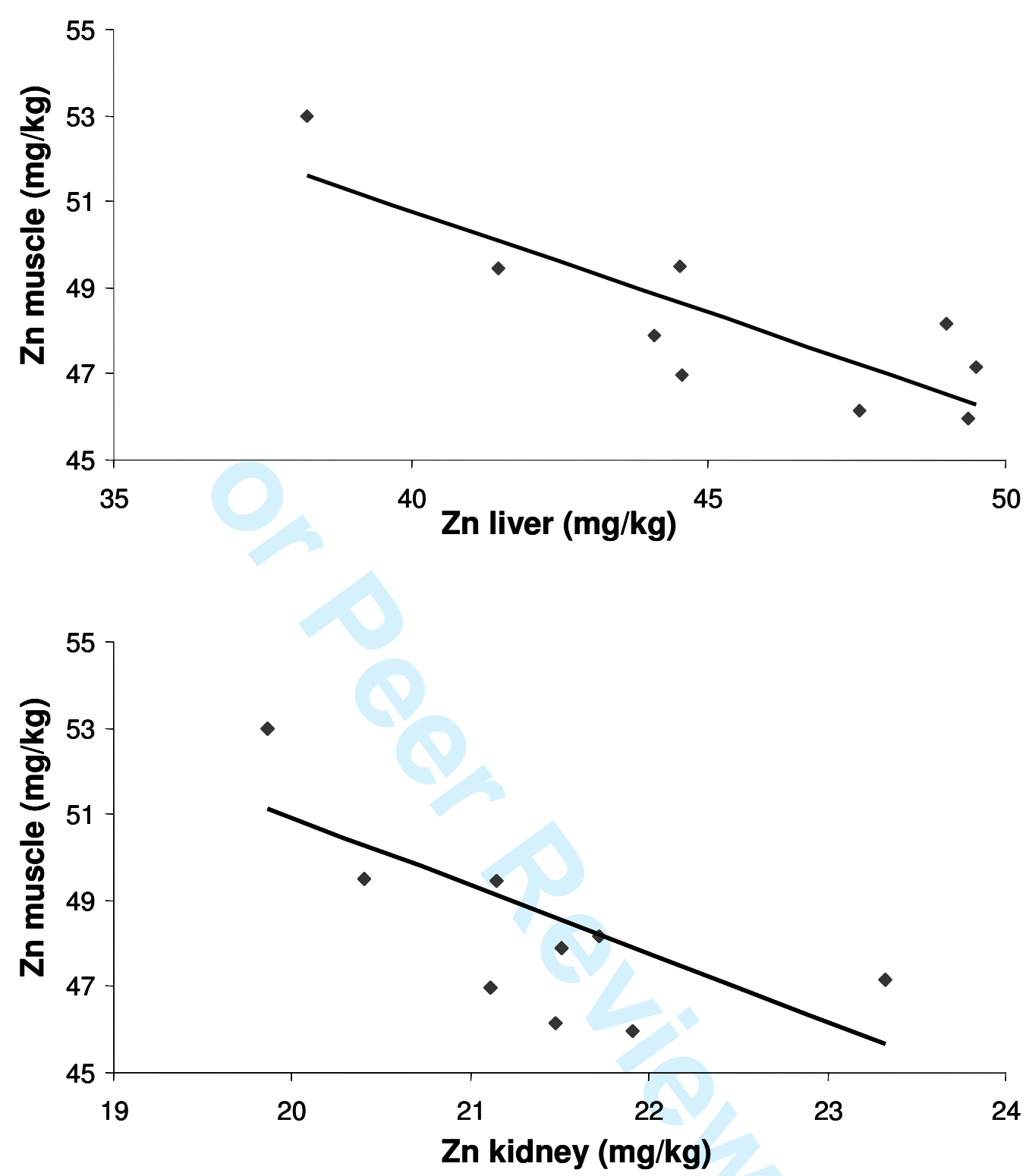

Figure 3. 